U.S. DEPARTMENT OF THE INTERIOR

U.S. GEOLOGICAL SURVEY

\title{
Gravity data along LARSE (Los Angeles Regional Seismic Experiment) Line II, southern California
}

by R.J. Wooley ${ }^{1}$ and V.E. Langenheim ${ }^{1}$

Open-File Report 01-375

2001

This report is preliminary and has not been reviewed for conformity with U.S. Geological Survey editorial standards or with the North American Stratigraphic Code. Any use of trade, firm, or product names is for descriptive purposes only and does not imply endorsement by the U.S. Government.

U.S. DEPARTMENT OF THE INTERIOR

U.S. GEOLOGICAL SURVEY

${ }^{1}$ Menlo Park, California 


\section{TABLE OF CONTENTS}

Abstract

\section{FIGURES}

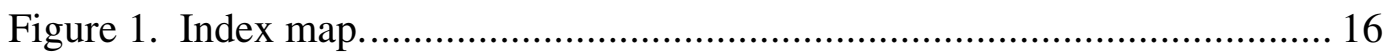

Figure 2. Map of gravity station coverage ................................................. 17

Figure 3. Simplified geology with physical property sample locations ............. 18

Figure 4a. Complete Bouguer gravity map.............................................. 19

Figure 4b. Isostatic gravity map............................................................ 20

Figure 5a. Complete Bouguer gravity profile ........................................... 21

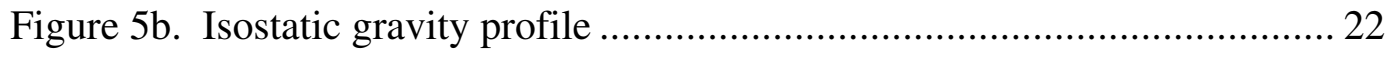

\section{TABLES}

Table 1a. Densities. ............................................................................ 9

Table 1b. Magnetic susceptibilities ...................................................... 9 


\begin{abstract}
The U.S. Geological Survey conducted a detailed gravity study along part of the Los Angeles Regional Seismic Experiment (LARSE) transect across the San Fernando Basin and Transverse Ranges to help characterize the structure underlying this area. Gravity measurements were collected at 249 new locations along the transect and to augment regional coverage near the profile. An isostatic gravity low of 50-60 mGal reflects the San Fernando-East Ventura basin. Another prominent isostatic gravity low with an amplitude of $30 \mathrm{mGal}$ marks the Antelope Valley basin. Gravity highs occur over the Santa Monica Mountains and the Transverse Ranges. The highest isostatic gravity values coincide with outcrops of Pelona schist.
\end{abstract}

\title{
Introduction
}

The U.S. Geological Survey (USGS) conducted a detailed gravity study consisting of 249 new gravity stations along Line 2 of the Los Angeles Regional Seismic Experiment (LARSE). LARSE consists of two main transects (LARSE I and LARSE II) which are approximately centered on the San Andreas fault in southern California (fig. 1). LARSE I, conducted in 1994 and $160 \mathrm{~km}$ long, crosses the Los Angeles basin, San Gabriel Mountains, and Mojave Desert. An earlier report describes gravity data collected along LARSE I (Langenheim and Jachens, 1996). LARSE II, carried out in 1999 and $150 \mathrm{~km}$ long, crosses the Santa Monica Mountains, San Fernando Valley Basin, Santa Susana Mountains, central Transverse Ranges, and western Mojave Desert (fig. 1). The goal of these two transects is to better assess earthquake hazards in southern California by determining sedimentary basin structure and thickness and by delineating the interconnection of faults at depth. Gravity data are useful in determining basin thickness 
because of the generally large density contrast between low-density basin deposits and dense crystalline basement rocks. Gravity and seismic data are complementary in that velocity data provide constraints on subhorizontal interfaces, whereas gravity data image steep boundaries well. Furthermore, gravity (and magnetic data) can be used to extrapolate geologic structure in the areas between the two LARSE transects, which are 50-75 km apart in a region known for its geologic complexity.

\section{Acknowledgments}

We would like to thank the U.S. Forest Service, the Gas Company, The Oaks Christian Camp, and the Castaic Lake Water Agency for allowing access to their land. We also thank Gary Fuis and Janice Murphy (U.S. Geological Survey, Menlo Park, Calif.) for their help in establishing these important land-access contacts.

\section{Gravity Data}

The USGS collected 249 gravity measurements with LaCoste \& Romberg gravity meters G-17C and G-8n in the study area (fig. 2) to provide detailed data over the seismic transect and supplement regional gravity coverage (more than 18,000 stations; Snyder and others, 1981). In February and October, 2000, gravity stations collected along the 
transect were collected, with 41 additional gravity stations collected to augment the gravity coverage to either side of the transect. The new data collected south of San Fernando Valley were tied to base station PB0104, with an observed gravity value of, 979,551.34 mGal ( Roberts and Jachens, 1986). Gravity data in the Santa Susana and San Gabriel Mountains south of San Andreas fault were tied to base station PB0111, with an observed gravity value 979,491.813 mGal ( Roberts and Jachens, 1986). Data collected in the Mojave Desert and San Gabriel Mountains north of the San Andreas fault were tied to base station PB0205 with an observed gravity value of 979414.785 (Roberts and Jachens, 1986).

Gravity data were reduced using the Geodetic Reference System of 1967 (International Union of Geodesy and Geophysics, 1971) and referenced to the International Gravity Standardization Net 1971 gravity datum (Morelli, 1974, p. 18). Gravity data were reduced to complete Bouguer and isostatic residual anomalies using a reduction density of $2670 \mathrm{~kg} / \mathrm{m}^{3}$. These data have been corrected for earth-tide, instrument drift, free-air, Bouguer, latitude, curvature, and terrain. An isostatic correction using a sea-level crustal thickness of $25 \mathrm{~km}$, a crustal density of $2670 \mathrm{~kg} / \mathrm{m}^{3}$, and a mantle-crust density contrast of $400 \mathrm{~kg} / \mathrm{m}^{3}$ was applied to the gravity data to remove long-wavelength crustal gravity effects due to topographic loading (Jachens and Roberts, 1981). 
U.S. G.S. 7-1/2 minute topographic series maps and Global Positioning System observations provided horizontal control on the gravity station locations U.S. G.S. 7-1/2 minute series maps, provided a majority of the station elevations in the mountainous areas along the LARSE transect. The uncertainty in the elevations of the stations is primarily controlled by the contour interval of the topographic maps and probably ranges from $3 \mathrm{~m}$ to $6 \mathrm{~m}$, with a corresponding uncertainty in the reduced gravity values of about $0.6 \mathrm{mGal}$ to $2.5 \mathrm{mGal}$.

Terrain corrections were computed to a radial distance of $167 \mathrm{~km}$ and involved a 3part process: (1) Hayford-Bowie zones A and B with an outer radius of $68 \mathrm{~m}$ were estimated in the field with the aid of tables and charts, (2) Hayford-Bowie zones C and D with an outer radius of $590 \mathrm{~m}$ were computed using a digital elevation model (DEM) and a procedure by Plouff (1977), and (3) terrain corrections from a distance of $0.59 \mathrm{~km}$ to $167 \mathrm{~km}$ were also calculated from a DEM. Total terrain corrections for the stations collected for this study ranged from $0.58 \mathrm{mGal}$ to $12.78 \mathrm{mGal}$, averaging $2.64 \mathrm{mGal}$. Uncertainties in the resulting terrain corrections probably range from less than $0.6 \mathrm{mGal}$ in the relatively flat areas of the San Fernando Valley and Mojave Desert to as much as $1.3 \mathrm{mGal}$ in the most mountainous part of the San Gabriel Mountains. 


\section{Physical Property Data}

Density and magnetic susceptibility data were also compiled and collected for this

study. These data can help determine the sources of gravity and magnetic anomalies and constrain 2- and 3-D modeling of potential-field data. Average density and magnetic susceptibility values for six geographic regions (fig. 3) were determined from 517 samples in (Geophysical Unit of Menlo Park, written communication 2001) physical property database, U. S. Geological Survey (fig. 3; table 1a and 1b). Samples from each region are separated into groups that represent basement and non-basement rocks. The LARSE II transect crosses the Santa Monica Mountains, Northern and Southern San Gabriel Mountains, and Mojave Desert regions. Basement rocks include mostly preCenozoic plutonic and metamorphic rocks while non-basement rocks include Cenozoic sedimentary and volcanic rocks (fig. 3). Basement rocks in the Santa Monica Mountains region also include Mesozoic marine sediments. In the Northern San Gabriel and Mojave regions, samples from the Pelona schist are listed separately from other basement rocks. The average basement densities for these regions are 2640, 2710, 2710, and $2660 \mathrm{~kg} / \mathrm{m}^{3}$, respectively: Basement samples in these regions include some weathered granitic rock samples which results in lower than expected densities for these areas (e.g. $2420 \mathrm{~kg} / \mathrm{m}^{3}$ for basement in the Santa Monica Mountain region). Samples of Pelona schist in the San Gabriel region have an average density of $2700 \mathrm{~kg} / \mathrm{m}^{3}$, a value similar to other basement 
rocks of the region. The Pelona schist and Santa Monica Mountains basement rocks are weakly magnetic, with average susceptibilities of 0.04 and $0.01 \times 10^{-3} \mathrm{cgs}$ units, respectively. Magnetic basement rocks are present in the San Gabriel Mountains, with average susceptibilities of 0.85 and $0.72 \times 10^{-3} \mathrm{cgs}$ units for the Northern and Southern San Gabriel regions respectively.

Previous work along the LARSE I transect indicated that the average density of 102 samples of crystalline rocks in the San Gabriel region is $2730 \mathrm{~kg} / \mathrm{m}^{3}$ and the average density of 111 samples of pre-Cenozoic rocks in the Mojave region is $2670 \mathrm{~kg} / \mathrm{m}^{3}$ (Langenheim, 1999). Most of the exposed rocks in the Mojave region are intrusive rocks with an average of $2650 \mathrm{~kg} / \mathrm{m}^{3}$ (based on 68 samples; Langenheim. 1999). This average is substantially higher than that reported in McCaffree Pellerin and Christensen (1998) for four samples near the LARSE I transect $\left(2603 \mathrm{~kg} / \mathrm{m}^{3}\right)$, but is nearly identical to our average density for 155 samples $\left(2660 \mathrm{~kg} / \mathrm{m}^{3}\right)$. 
Table 1a. Average densities of basement and non-basement rocks

\begin{tabular}{|c|c|c|c|}
\hline & Number & $\begin{array}{l}\text { Average Density } \\
\mathrm{kg} / \mathrm{m}^{3}\end{array}$ & $\begin{array}{l}\text { Range in Density } \\
\mathrm{kg} / \mathrm{m}^{3}\end{array}$ \\
\hline \multicolumn{4}{|l|}{ Northern San Gabriel } \\
\hline$\overline{\text { Basement (excluding Pelona Schist) }}$ & 82 & 2710 & $2560-3390$ \\
\hline Pelona Schist & 13 & 2700 & $2660-2840$ \\
\hline Non-basement & 14 & 2510 & $2080-2660$ \\
\hline \multicolumn{4}{|l|}{ Southern San Gabriel } \\
\hline Basement (excluding Pelona Schist) & 76 & 2710 & $2520-2960$ \\
\hline Non-basement & 7 & 2460 & $2170-2710$ \\
\hline \multicolumn{4}{|l|}{ Santa Monica Mountains } \\
\hline Basement & 12 & 2640 & $2420-2750$ \\
\hline Non-basement & 6 & 2480 & $2190-2720$ \\
\hline \multicolumn{4}{|l|}{ Mojave Desert } \\
\hline$\overline{\text { Basement }}$ & 155 & 2660 & $2550-2830$ \\
\hline Non-basement & 11 & 2420 & $2290-2650$ \\
\hline \multicolumn{4}{|l|}{ Southern Sierra/ Tehachapi Mnts } \\
\hline Basement & 120 & 2740 & $2560-3020$ \\
\hline Non-basement & 2 & 2510 & $2490-2540$ \\
\hline \multicolumn{4}{|l|}{ Western Transverse Ranges } \\
\hline Basement & 13 & 2690 & $2650-2750$ \\
\hline Non-basement & 2 & 2570 & $2550-2600$ \\
\hline
\end{tabular}

Table 1b. Average susceptibility of basement and non-basement rocks

\begin{tabular}{|c|c|c|c|}
\hline & Number & $\begin{array}{l}\text { Ave. } \\
\text { Susceptibility } 10^{-3} \\
\text { cgs }\end{array}$ & $\begin{array}{l}\text { Range in Susceptibility } \\
10^{-3} \mathrm{cgs}\end{array}$ \\
\hline \multicolumn{4}{|l|}{ Northern San Gabriel } \\
\hline Basement (excluding Pelona Schist) & 17 & 0.85 & $0.00-7.11$ \\
\hline Pelona Schist & 14 & 0.04 & $0.01-0.14$ \\
\hline Non-basement & 13 & 0.03 & $0.00-0.20$ \\
\hline \multicolumn{4}{|l|}{$\underline{\text { Southern San Gabriel }}$} \\
\hline Basement & 59 & 0.72 & $0.00-3.69$ \\
\hline Non-basement & 12 & 0.21 & $0.00-0.75$ \\
\hline \multicolumn{4}{|l|}{ Santa Monica Mountains } \\
\hline Basement & 11 & 0.01 & $0.00-0.02$ \\
\hline Non-basement & 6 & 0.03 & $0.00-0.10$ \\
\hline \multicolumn{4}{|l|}{ Mojave Desert } \\
\hline Basement & 90 & 0.08 & $0.00-1.11$ \\
\hline Non-Basement & 4 & 0.06 & $0.00-0.20$ \\
\hline \multicolumn{4}{|l|}{ Southern Sierra/ Tehachapi Mnts } \\
\hline Basement & 83 & 0.02 & $0.00-0.14$ \\
\hline Non-basement & 2 & 0.00 & $0.00-0.00$ \\
\hline
\end{tabular}




\section{Gravity Anomalies Along the LARSE II Profile}

The complete Bouguer gravity anomaly reflects density variations throughout the crust, including the lower crust and mantle, whereas isostatic gravity anomalies generally reflect lateral density variations in the middle to upper crust (Simpson and others, 1986). Langenheim and Hauksson (2001) compared the predicted gravity from a three-dimensional velocity model with the isostatic gravity field in southern California and showed that, in general, the isostatic gravity field reflects density variations in the upper $10 \mathrm{~km}$. Thus, isostatic gravity anomalies provide a convenient starting point for separating the gravity field into basement and basin components. However, the isostatic gravity field is a modeled result and therefore may improperly remove long-wavelength variations not caused by a compensating isostatic root. For this reason, we present maps and profiles of both the complete Bouguer gravity and isostatic gravity anomalies. The new data were combined with existing data and gridded to produce complete Bouguer and isostatic gravity maps (figs. $4 \mathrm{a}$ and $4 \mathrm{~b}$ ). The new and old data within $1 \mathrm{~km}$ of the LARSE II transect are also shown in profile form along the LARSE II transect (figs. 5a and $5 b)$.

The complete Bouguer gravity data indicate a long-wavelength decrease in values

from the coast to the Mojave Desert. Superposed on this long-wavelength decrease are gravity lows associated with the San Fernando Valley-East Ventura basin and the 
Antelope Valley basin in the western Mojave Desert (fig 5a). The gravity lows associated with these depressions are enhanced by the isostatic correction as are the gravity highs associated with the San Gabriel Mountains and the Santa Monica Mountains (fig. 5b).

Near the coast, the isostatic gravity values increase rapidly to the north from the southern end of the transect. They peak at values around $0 \mathrm{mGal}$ at $8 \mathrm{~km}$ from the south end of the profile, over the Santa Monica Mountains which is composed of JurassicTriassic meta-sediments, also known as the Santa Monica Slate. The values then decrease into the San Fernando Basin. The values reach a minimum of just below -50 $\mathrm{mGal}$ at about $\mathrm{km} 28$. The isostatic values increase near the Santa Susana thrust fault to a local high of $-35 \mathrm{mGal}$ near the San Gabriel Fault at about km 42. This is followed by a section where the values remain around $-36 \mathrm{mGal}$ for $5-\mathrm{km}$ and this corresponds to an area where the trend of the profile parallels the gravity contours associated with the Soledad basin (fig. 4b). The isostatic gravity field then increases as it transects crystalline rocks in the San Gabriel Mountians. The Bouguer gravity profile is relatively flat through the San Fernando basin with a local high at the approximate intersection with the San Gabriel fault followed by an increase as the profile crosses the San Gabriel Mountains (see Fig. 5a).

The highest isostatic gravity values on the entire profile are at about $9 \mathrm{mGal}$ at $\mathrm{km} 58$ that corresponds to the area along the profile where Pelona schist is exposed at the 
surface. A sharp 5-mGal decrease in the isostatic gravity occurs where the profile intersects the Clearwater fault at $\mathrm{km} 63$. This is caused by the contact between Eocene sedimentary rocks and crystalline basement. Another local high on the isostatic and Bouguer profiles occurs at $\mathrm{km} 67$ that is partially attributable to a change in the trend of the LARSE II profile as it parallels the contours of the gravity gradient.

The San Andreas fault occurs near km 75 and is marked by a gentle gravity gradient that has an amplitude of $15 \mathrm{mGal}$. Stations near the San Andreas fault are noisy (isostatic values ranging from -12 to $-16 \mathrm{mGal}$ over a distance of $6 \mathrm{~km}$ ), because the LARSE II seismic profile, which dictated the location of gravity stations, is so crooked in this area.

North of the San Andreas fault zone, the isostatic values drop steeply as the line crosses the Antelope Valley basin in the Mojave Desert. The lowest values along the profile in the Mojave Desert region (-45 mGal) occur just 14-17 km north of the San Andreas fault (fig. 5b). North of this low, the values increase as the basin shallows toward the Tehachapi Mountains. 


\section{Conclusions}

Gravity profiles along LARSE II display high values associated with the Santa Monica and San Gabriel Mountains and low values associated with the San Fernando-East Ventura and Antelope Valley basins. The highest gravity values in the San Gabriel Mountains coincide with exposures of Pelona schist. The San Andreas fault is marked by a gentle gravity gradient that has an amplitude of $15 \mathrm{mGal}$. Interpretation of the gravity profile is complicated by the highly 3-dimensional nature of the geologic structure in the area of the LARSE II profile as well as changes in local azimuth of the profile relative to the geologic structure. Measurements of physical property data for the San Gabriel and Mojave regions near LARSE II tend to agree with measurements of samples near LARSE

I. The Pelona schist is observed as being dense and weakly magnetic. Gravity and physical property data observed in this study will contribute to future modeling and interpretations in the area of the LARSE II transect. 


\section{References}

International Union of Geodesy and Geophysics, 1971, Geodetic Reference System 1967:

International Association of Geodesy Special Publication no. 3, 116 p.

Jachens, R.C., and Roberts, C.W., 1981, Documentation of a FORTRAN program

'isocomp', for computing isostatic residual gravity: U.S. Geological Open-File Report $81-574,26 \mathrm{p}$.

Jennings, C.W., 1994, Fault activity map of California and adjacent areas: California Division of Mines and Geology California Geologic Data Map 6, scale 1:750,000.

Langenheim, V.E., 1999, Gravity and aeromagnetic models along the Los Angeles

Regional Seismic Experiment (Line 1), California: USGS Open-File Report 99-388, 22p.

Langenheim, V.E., and Hauksson, Egill, 2001, Comparison between crustal density and velocity variations in southern California: Geophysical Research Letters, v. 28, p. 3087-3090.

Langenheim, V.E., and Jachens, R.C., 1996, Gravity data collected along the Los Angeles Regional Seismic Experiment (LARSE) and preliminary model of regional density variations in basement rocks, southern California: U.S. Geological Survey Open-File Report 96-682. 
McCaffree Pellerin, C.L., and Christensen, N.I., 1998, Interpretation of crustal seismic velocities in the Mojave-San Gabriel region, southern California: Tectonophysics, v. 286, p. 253-271.

Morelli, C.(Ed.), 1974, The International Gravity Standardization Net, 1971: International Association of Geodesy Special Publication no. 4, 194 p.

Snyder, D.B., Roberts, C.W., Saltus, R. W., and Sikora, R. F. 1981, Magnetic tape containing the principal facts of 64,402 gravity stations in the State of California:

U.S. Geological Survey Report, 30 p.; available from the National Technical Information Service, U.S. Department of Commerce, Springfield, Virginia 22161, PB82-168287

Plouff, Donald, 1977, Preliminary documentation for a FORTRAN program to compute gravity terrain corrections based on topography digitized on a geographic grid: U.S. Geological Survey Open-File Report 77-535, 45 p.

Roberts, C.W., and Jachens, R.C., 1986, High-precision gravity stations for monitoring vertical crustal motion in southern California: U.S. Geological Survey Open-File Report 86-44, 76 p.

Simpson, R.W., Jachens, R.C., Blakely, R.J., and Saltus, R.W., 1986, A new isostatic residual gravity map of the conterminous United States with a discussion on the significance of isostatic residual anomalies: Journal of Geophysical Research, v. 91, p. $8348-72$. 


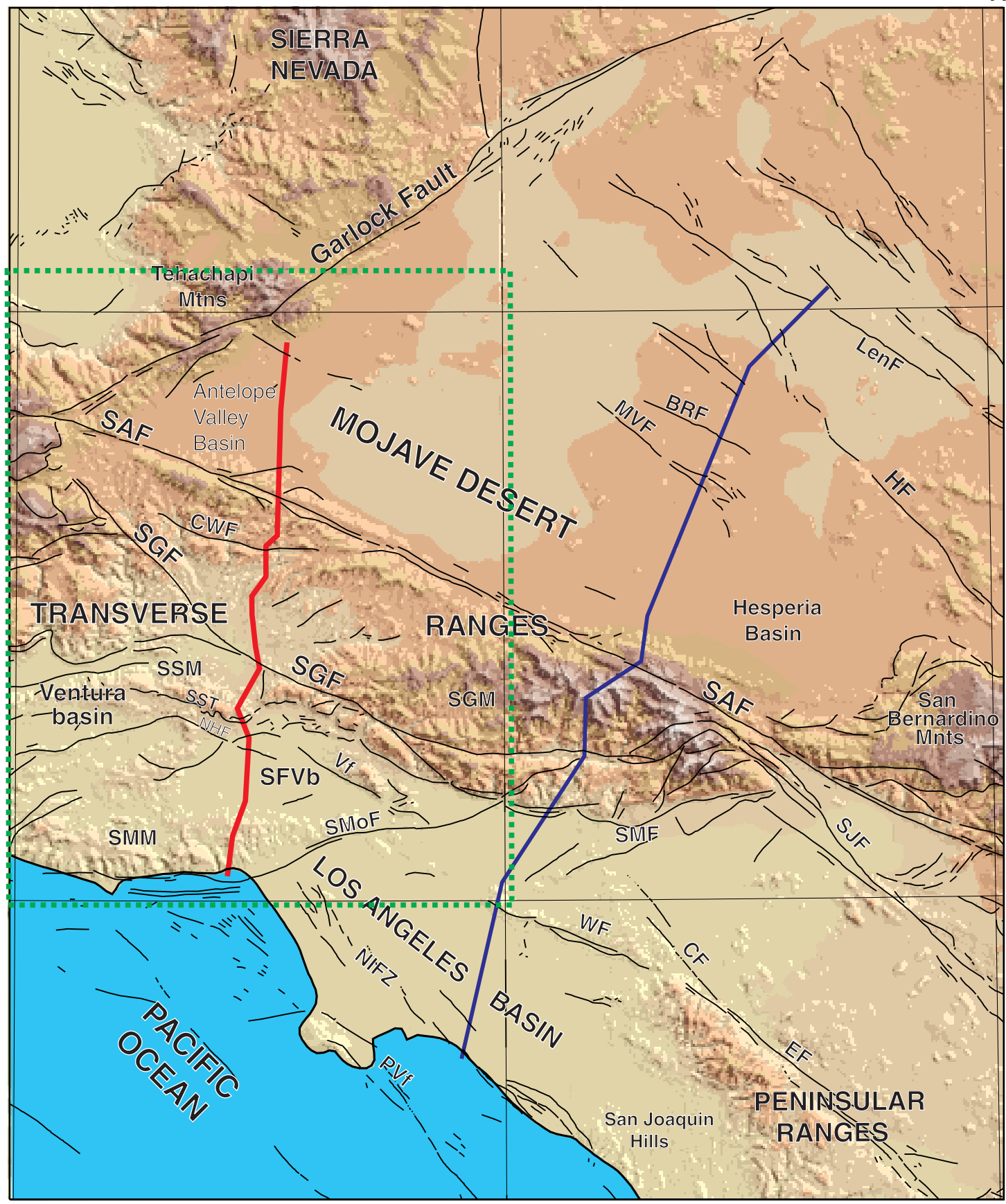

Figure 1. Shaded-relief terrain map of southern California showing location of the LARSE II transect (red line). Blue line shows location of LARSE I transect. Green outline shows area location of study area. Black lines are fault locations from Jennings (1994). BRF, Blake Ranch fault; CF, Chino fault; CWF, Clearwater fault; EF, Elsinore fault; HF, Helendale fault; LenF, Lenwood fault; MVF, Mirage Valley fault; NHF,Northridge Hills fault; NIFZ,

Newport-Inglewood fault zone; PVf, Palos Verdes fault; SAF, San Andreas fault; SFVb, San Fernando Valley basin; SGF, San Gabriel fault; SGM, San Gabriel Mountains; SJF, San Jacinto fault; SMF, Sierra Madre fault; SMoF, Santa Monica fault; SMM, Santa Monica Mountains; SSM, Santa Susana Mountains; SST, Santa Susana Thrust; VF, Verdugo fault; WF, Whittier fault. 


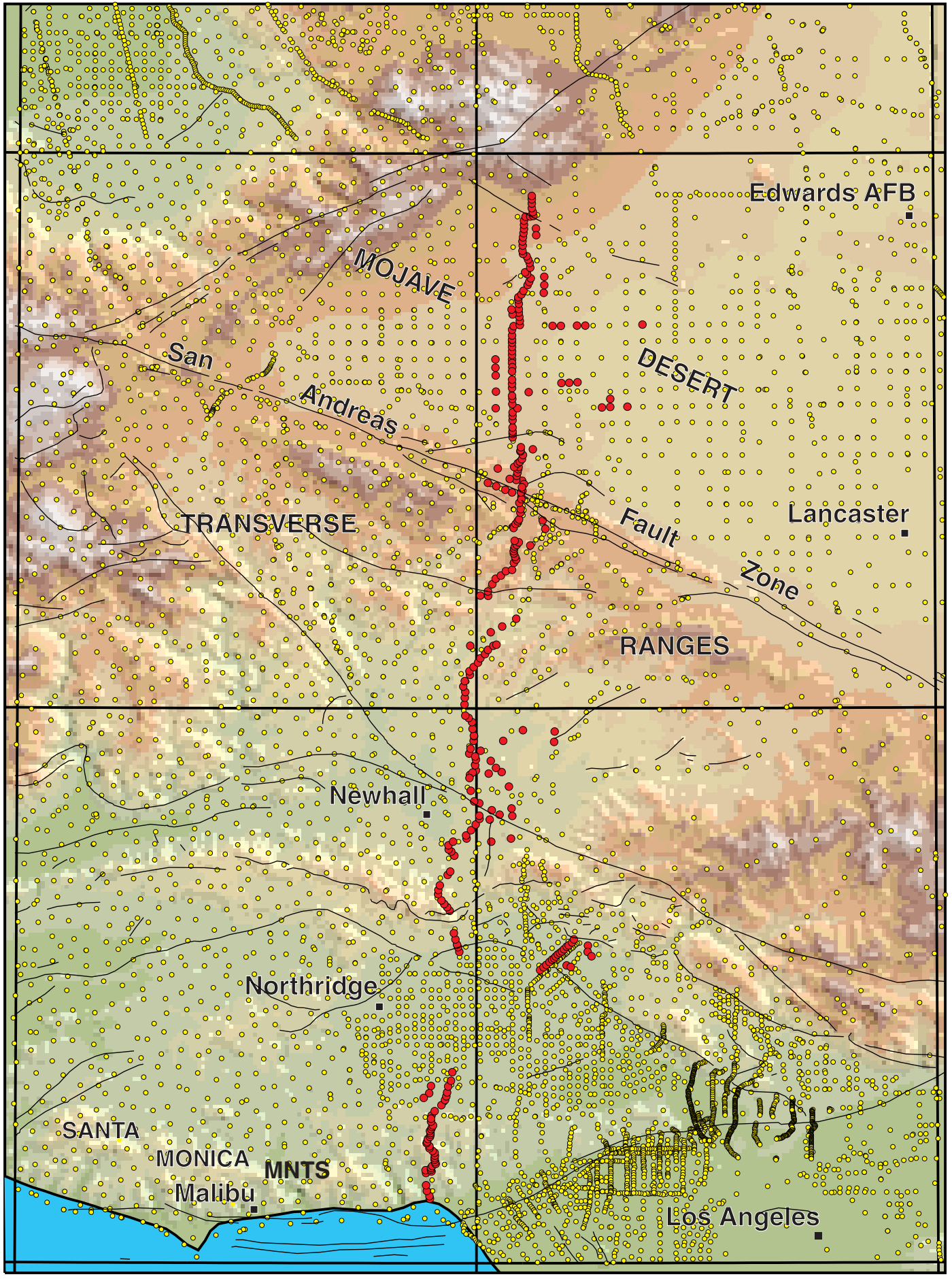

Figure 2. Map of gravity station coverage. Red circles are new stations described in this report. Yellow circles are previously collected stations. Fault locations from Jennings (1994). 


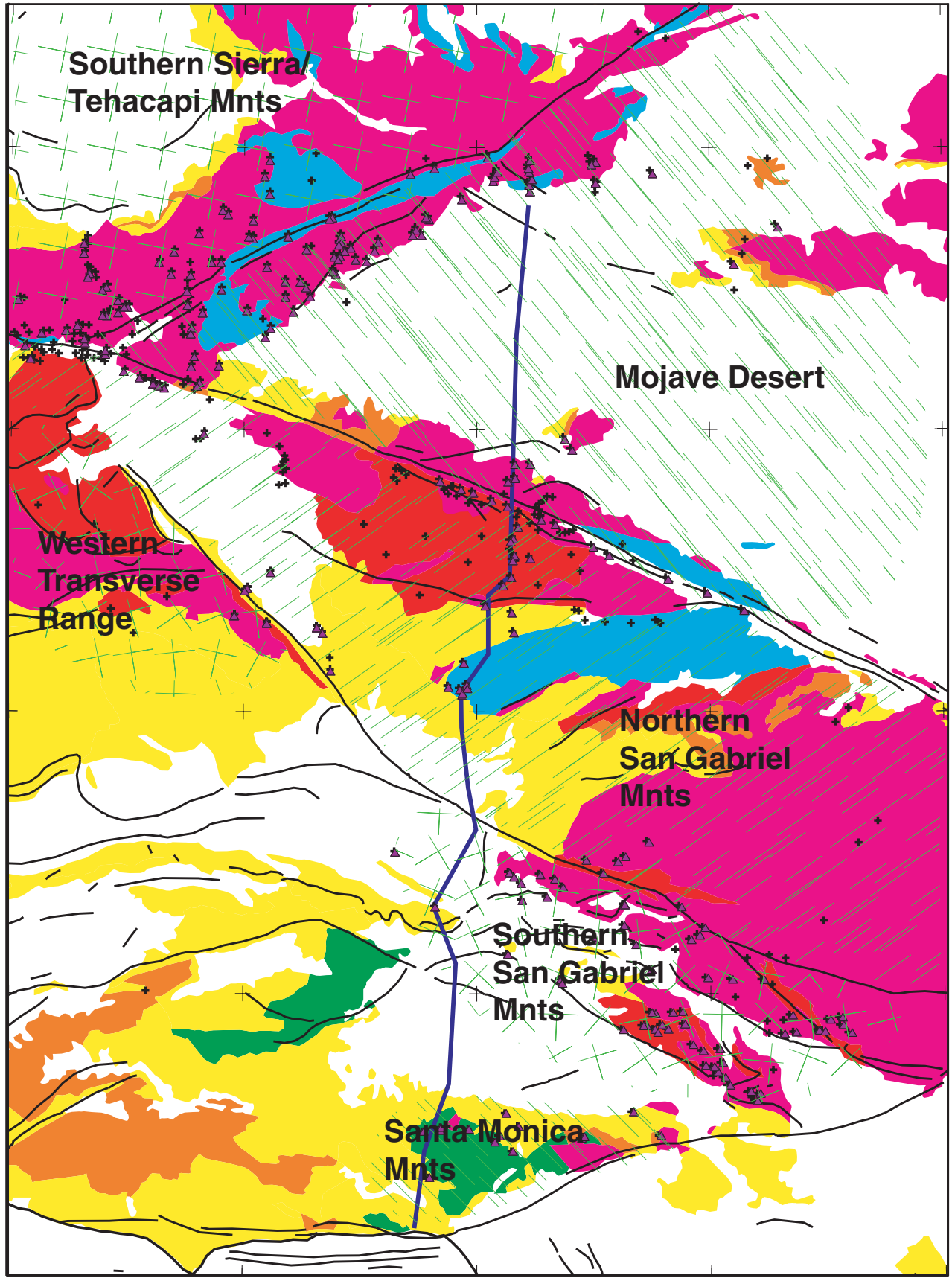

$35^{\circ}$
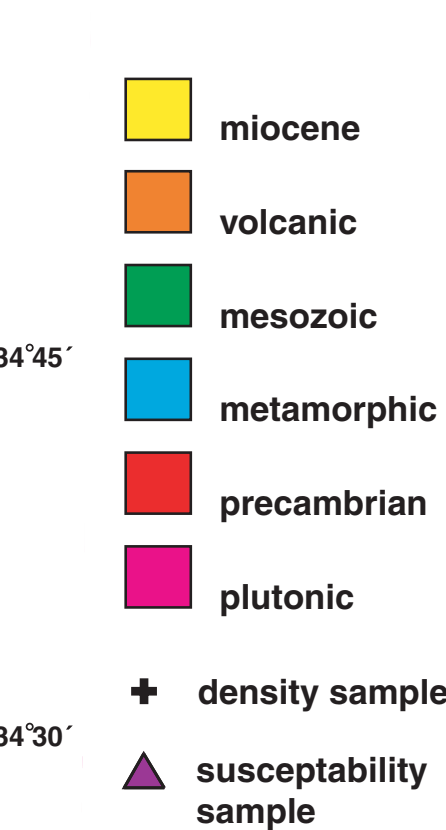

$34^{\circ} 15^{\prime}$

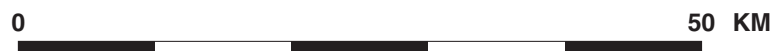

Figure 3. Simplified geology of the study area showing physical property measurement locations and regions. Blue lineis LARSE II profile. Green hachures show areas of physical property regions (tables 1a and 1b). Faults from Jennings (1994). 

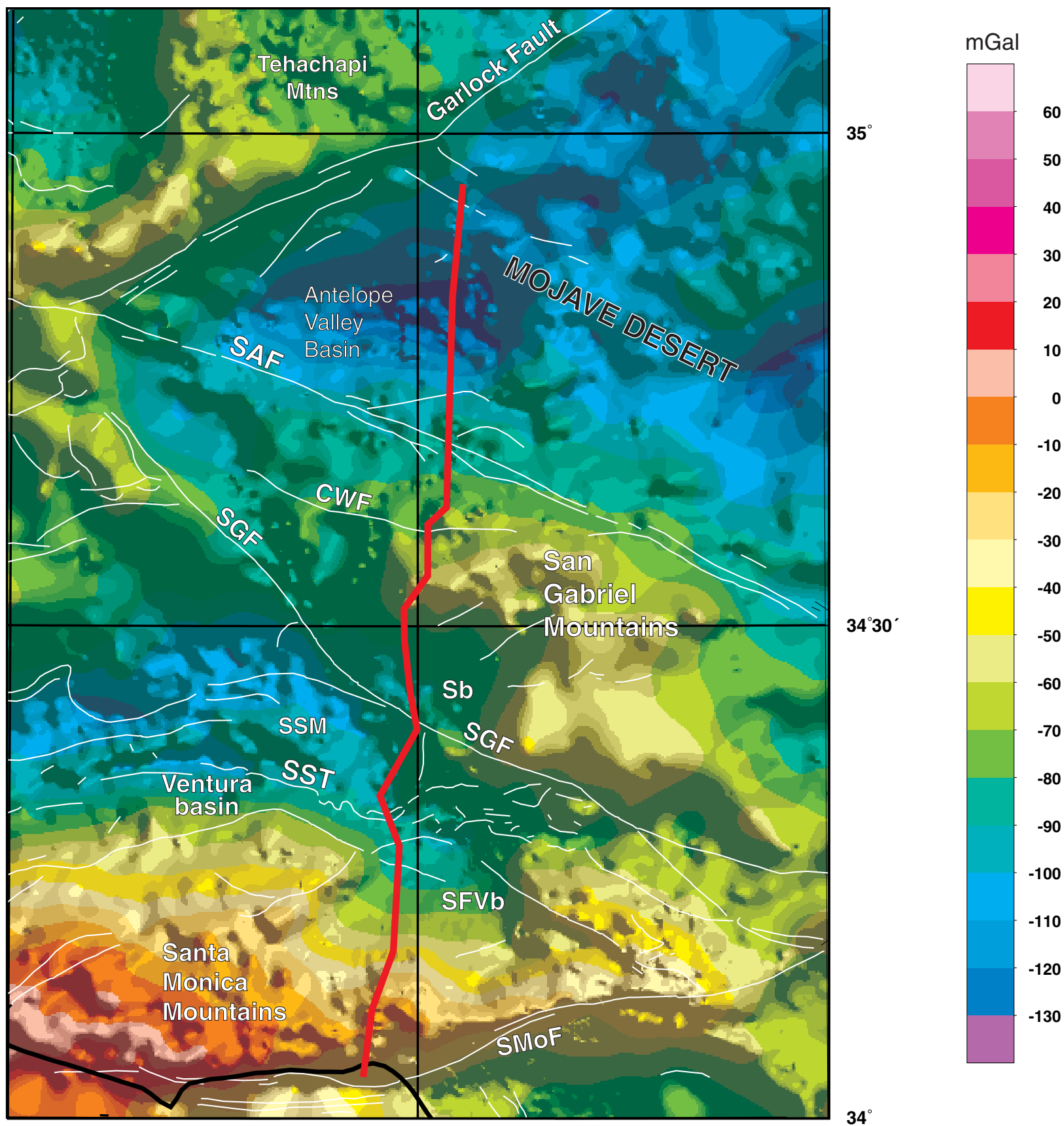

$34^{\circ}$

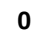

$50 \mathrm{KM}$

Figure 4a. Complete Bouguer gravity map. Red line is LARSE II profile. Contour interval $10 \mathrm{mGal}$. White lines are fault locations from Jennings (1994). CWF, Clearwater Fault; SAF, San Andreas Fault; Sb, Soledad basin; SFVb, San Fernando Valley basin; SGF, San Gabriel Fault; SmoF, Santa Monica Mountains; SSM, Santa Susana Mountains; SST, Santa Susana Thrust. 
